\title{
AKTIVITAS ANTIBAKTERI EKSTRAK DAUN JARAK PAGAR (JATROPHA CURCAS L) TERHADAP STAPHYLOCOCCUS EPIDERMIDIS DAN STAPHYLOCOCCUS AUREUS SECARA IN VITRO
}

\author{
Susilo Yulianto, Sunarmi \\ Kementerian Kesehatan Politeknik Kesehatan Surakarta Jurusan Jamu
}

\begin{abstract}
Jatropha Leaves, Staphylococcus Epidermidis, Staphylococcus Aureus. Jatropha curcas L leaves contain tannins, saponins and flavonoids. According to some studies, tannins, saponins and flavonoids have antibacterial power. Based on these indications, it is important to do research on antibacterial potency of jatropha leaf extract (Jatropha curcas L) against Staphylococcus epidermidis and Staphylococcus aureus bacteria. The aim of this research is to know Antibacterial Activity of Jatropha curcas L Extract on Staphylococcus epidermidis and Staphylococcus aureus". This research. An experimental study by testing the antibacterial activity of leaf extract and jatropha result of maceration, infundation and reflux as measured by Minimal Inhibitory Concentration (KHM) on growth of Staphylococcus epidermidis and Staphylococcus aureus bacteria. From the results of the research, it was found that the extract of the reflux was brownish green and the characteristic of jatropha leaves. The amount of extract produced was $17.03 \mathrm{~g}$, so the yield was $17.03 \%$. Jatropha leaf extract of maceration has no inhibitory power to $S$. epidermidis in 4 series concentrations starting from $3.125 \mathrm{ppm}$ to $25.000 \mathrm{ppm}$. Inhibitory zones begin to appear at concentrations of 50,000 ppm and increase at concentrations of 100,000 ppm. The drag zone diameter in the Jatropha curcas extract of the reflux showed the inhibitory power in all series of concentrations. The smallest inhibitory zone was shown at a concentration of 3,125 ppm $(9.33 \mathrm{~mm})$ and increased with increasing concentrations. The diameter of the inhibit zone was greatest at 100,000 ppm concentrations of 22.67 mm. Description of inhibitory zone diameter of methanol leaf extract of jatropha result of maceration and reflux to $S$. epidermidis. The conclusion of this research is extract of reflux result giving bigger resistance than maceration extract to $S$. epidermidis and $S$. aureus. Methanol extract of jatropha from the maceration and reflux have strong antibacterial activity against $S$. epidermidis and $S$. aureus but still under Klindamycin.
\end{abstract}

Keywords: Jatropha Leaves, Staphylococcus Epidermidis, Staphylococcus Aureus

Abstrak: Daun Jarak Pagar, Staphylococcus Epidermidis, Staphylococcus Aureus. Daun jarak pagar (Jatropha curcas L) memiliki kandungan tanin, saponin dan flavonoid. Menurut beberapa penelitian, tanin, saponin dan flavonoid ini memiliki daya antibakteri. Berdasarkan adanya indikasi tersebut, maka penting dilakukan penelitian tentang potensi antibakteri ekstrak daun jarak pagar (Jatropha curcas L) terhadap bakteri Staphylococcus epidermidis dan Staphylococcus aureus. Penelitian ini bertujuan untuk mengetahui Aktivitas Antibakteri Ekstrak Daun Jarak Pagar (Jatropha curcas L) Terhadap Staphylococcus epidermidis dan Staphylococcus aureus". Penelitian ini, merupakan penelitian eksperimental dengan menuji aktivitas antibakteri ekstrak daun 
dan jarak pagar hasil maserasi, infundasi dan refluks yang diukur dengan Konsentrasi hambat Minimal (KHM) terhadap pertumbuhan bakteri Staphylococcus epidermidis dan Staphylococcus aureus. Dari hasil penelitian didapatkan bahwa ekstrak hasil refluks berwarna hijau kecoklatan dan berbau khas daun jarak pagar. Jumlah ekstrak yang dihasilkan sebanyak 17,03 g, sehingga besar rendemen adalah 17,03 \%. Ekstrak daun jarak pagar hasil maserasi tidak memiliki daya hambat terhadap S. epidermidis pada 4 seri konsentrasi mulai $3.125 \mathrm{ppm}$ sampai $25.000 \mathrm{ppm}$. Zona hambat mulai terlihat pada konsentrasi $50.000 \mathrm{ppm}$ dan semakin meningkat pada konsentrasi $100.000 \mathrm{ppm}$. Diameter zona hambat pada ekstrak daun jarak pagar hasil refluks menunjukkan adanya daya hambat pada semua seri konsentrasi. Zona hambat paling kecil ditunjukkan pada konsentrasi $3.125 \mathrm{ppm}(9,33 \mathrm{~mm})$ dan semakin meningkat seiring dengan peningkatan konsentrasi. Diameter zona hambat paling besar pada konsentrasi 100.000 ppm sebesar 22,67 mm. Gambaran diameter zona hambat ekstrak metanol daun jarak pagar hasil maserasi dan refluks terhadap S. Epidermidis. Kesimpulan penelitian ini yaitu Ekstrak hasil refluks memberikan hambatan yang lebih besar dibanding ekstrak hasil maserasi terhadap S. epidermidis maupun S. Aureus. Ekstrak metanol daun jarak pagar hasil maserasi dan refluks memiliki aktivitas antibakteri yang kuat terhadap S. epidermidis maupun $S$. aureus namun masih di bawah Klindamycin.

\section{Kata Kunci: Daun Jarak Pagar, Staphylococcus Epidermidis, Staphylococcus Aureus}

\section{PENDAHULUAN}

Sejak jaman dahulu, manusia sangat mengandalkan lingkungan sekitarnya untuk memenuhi kebutuhannya, baik untuk makan, tempat berteduh, pakaian, obat, pupuk, parfum, dan bahkan untuk kecantikan dapat diperoleh dari lingkungan. Sehingga kekayaan alam di sekitar manusia sebenarnya sedemikian rupa sangat bermanfaat dan belum sepenuhnya digali, dimanfaatkan, atau bahkan dikembangkan. Bangsa Indonesia telah lama mengenal dan menggunakan ramuan herbal sebagai salah satu upaya dalam menanggulangi masalah kesehatan. Wawasan dan pengetahuan tentang tumbuhan yang menyehatkan berdasarkan pada pengalaman dan ketrampilan yang secara turun temurun telah diwariskan dari satu generasi ke generasi berikutnya

Alam Indonesia banyak menyimpan berbagai tumbuhan yang menyehatkan dan dihuni oleh berbagai suku dengan pengetahuan penyehatan tradisional yang berbeda. Indonesia memiliki lebih dari 1.000 jenis tumbuhan yang dapat digunakan untuk menyehatkan tubuh manusia, baru sekitar 300 jenis yang sudah digunakan untuk penyehatan tradisional (Hariana, 2004).

Pengalaman dan pengetahuan tentang penggunaan tumbuhan herbal yang menyehatkan yaitu pemanfaatan terhadap jenis tumbuhan yang terdapat di dalam hutan. Bentuk pemanfaatan tersebut diperoleh dari pengalaman dan kebiasaan seseorang yang kemudian diturunkan pada generasi berikutnya, sehingga pengetahuan yang berasal dari pengalaman dan kebiasaan tersebut hanya menjadi pengetahuan masyarakat setempat (Ajijah dan Iskandar, 1995 dalam Hara, 2013).

Ramuan herbal telah menjadi bagian budaya dan kekayaan alam 
Indonesia. Ramuan herbal merupakan bagian dari obat tradisional Indonesia yang berupa bahan tumbuhan, bahan hewan, bahan mineral, sediaan sarian (galenik) atau campuran dari bahan tersebut yang secara turun temurun telah digunakan untuk pengobatan dan dapat diterapkan sesuai dengan norma yang berlaku di masyarakat (Permenkes RI No. 003/MENKES/PER/I/2010).

Salah satu tumbuhan yang dapat dijadikan sebagai obat tradisional adalah tanaman jarak pagar (Jatropha curcas L). Tanaman jarak pagar (Jatropha curcas L) telah banyak digunakan masyarakat luas untuk dijadikan tanaman yang berkhasiat bagi kesehatan, dan secara empiris, getah tanaman ini telah digunakan masyarakat sebagai pengobatan jerawat, sariawan, obat luka dan penahan darah. Selain itu daun tanaman jarak juga digunakan sebagai obat demam, penangan rematik dan jaundice.

Daun tanaman jarak pagar (Jatropha curcas L) memiliki kandungan tanin, saponin dan flavonoid. Menurut beberapa penelitian, tanin, saponin dan flavonoid ini memiliki daya antibakteri. Berdasarkan adanya indikasi tersebut, maka penting dilakukan penelitian tentang potensi antibakteri ekstrak daun jarak pagar (Jatropha curcas L) terhadap bakteri Staphylococcus epidermidis dan Staphylococcus aureus.

\section{METODE PENELITIAN}

Rancangan penelitian ini eksperimental, untuk menguji aktivitas antibakteri ekstrak daun dan jarak pagar hasil maserasi, infundasi dan refluks yang diukur dengan konsentrasi hambat minimal (KHM) terhadap pertumbuhan bakteri Staphylococcus epidermidis dan Staphylococcus aureus.

\section{HASIL PENELITIAN}

\section{Ekstrak Daun Jarak Pagar}

Ekstraksi daun jarak pagar menggunakan metode maserasi dan refluks dengan perbandingan sampel dan pelarut 1 : 10. Ekstrak hasil maserasi berwarna hijau tua dan berbau khas daun jarak pagar. Jumlah ekstrak yang dihasilkan sebanyak 11,79 g, sehingga besar rendemen adalah 11,79\%.

Ekstrak hasil refluks berwarna hijau kecoklatan dan berbau khas daun jarak pagar. Jumlah ekstrak yang dihasilkan sebanyak 17,03 g, sehingga besar rendemen adalah 17,03\%.

\section{Aktivitas Antibakteri}

Penelitian ini direncanakan menguji aktivitas antibakteri ekstrak daun jarak pagar terhadap Staphylococcus epidermidis dan Staphylococcus aureus. Saat pelaksanaan penelitian, sampel bakteri $P$. acne tidak berhasil didapatkan, sehinggan diganti dengan Staphylococcus aureus. Penggunaan Staphylococcus aureus sebagai pengganti dengan pertimbangan bahwa Staphylococcus aureus memiliki peran terhadap timbulnya jerawat.

Ekstrak daun jarak pagar hasil maserasi tidak memiliki daya hambat terhadap S. epidermidis pada 4 seri konsentrasi mulai 3.125 ppm sampai $25.000 \mathrm{ppm}$. Zona hambat mulai terlihat pada konsentrasi 50.000 ppm dan semakin meningkat pada konsentrasi 100.000 ppm.

Diameter zona hambat pada ekstrak daun jarak pagar hasil refluks menunjukkan adanya daya hambat pada semua seri konsentrasi. Zona hambat paling kecil ditunjukkan pada konsentrasi $3.125 \mathrm{ppm}(9,33 \mathrm{~mm})$ dan semakin meningkat seiring dengan peningkatan konsentrasi. Diameter zona hambat paling 
besar pada konsentrasi 100.000 ppm sebesar 22,67 mm. Gambaran diameter zona hambat ekstrak metanol daun jarak pagar hasil maserasi dan refluks terhadap S. epidermidis terdapat pada tabel 1.

\section{Tabel 1}

Aktivitas Antibakteri Ekstrak Daun Jarak Pagar terhadap S. Epidermidis

\begin{tabular}{lll}
\hline Konsentrasi (ppm) & \multicolumn{2}{l}{$\begin{array}{l}\text { Diameter Zona Hambat } \\
(\mathbf{m m})\end{array}$} \\
& Maserasi & Refluks \\
\hline 100.000 & 19,33 & 22,67 \\
50.000 & 6,67 & 22,17 \\
25.000 & 0 & 14,83 \\
12.500 & 0 & 11,83 \\
6.250 & 0 & 11 \\
3.125 & 0 & 9,33 \\
\hline Klindamicin & \multicolumn{2}{c}{40,50} \\
Akuades & 0 \\
\hline
\end{tabular}

Ekstrak daun jarak pagar hasil maserasi memiliki daya hambat terhadap $S$. aureus pada semua seri konsentrasi. Zona hambat terkecil ditunjukkan pada konsentrasi $3.125 \mathrm{ppm}$ dan semakin meningkat seiring peningkatan konsentrasi dengan diameter zona hambat terbesar pada konsentrasi 100.000 ppm (31,00 mm).

Diameter zona hambat pada ekstrak daun jarak pagar hasil refluks menunjukkan adanya daya hambat pada semua seri konsentrasi. Zona hambat paling kecil ditunjukkan pada konsentrasi $3.125 \mathrm{ppm}(11,33 \mathrm{~mm})$ dan semakin meningkat seiring dengan penurunan konsentrasi. Zona hambat paling besar pada konsentrasi 100.000 ppm sebesar 29,67 mm, namun lebih kecil dibandingkan zona hambat ekstrak hasil maserasi. Gambaran diameter zona hambat ekstrak metanol daun jarak pagar hasil maserasi dan refluks terhadap $\mathrm{S}$. epidermidis terdapat pada tabel 2 .
Tabel 2

Aktivitas Antibakteri Ekstrak Daun

Jarak Pagar Terhadap S. Aureus

\begin{tabular}{lll}
\hline \multirow{2}{*}{$\begin{array}{c}\text { Konsentrasi } \\
(\mathbf{p p m})\end{array}$} & \multicolumn{2}{c}{$\begin{array}{c}\text { Diameter Zona Hambat } \\
(\mathbf{m m})\end{array}$} \\
& \multicolumn{1}{c}{ Maserasi } & Refluks \\
\hline 100.000 & 31 & 29,67 \\
50.000 & 23,17 & 32,5 \\
25.000 & 7,33 & 25,5 \\
12.500 & 6 & 21 \\
6.250 & 5,5 & 11,7 \\
3.125 & 5 & 11,33 \\
\hline Klindamicin 30 & \multicolumn{2}{c}{40,50} \\
Akuades & \multicolumn{2}{c}{0} \\
\hline \multicolumn{1}{c}{ Diame }
\end{tabular}

Diameter zona hambat pada semua variasi konsentrasi dan metode ekstraksi masih lebih kecil dibandingkan kontrol positif Klindamycin $30 \mu \mathrm{g} / \mathrm{ml}$ sebesar $40,50 \mathrm{~mm}$.

\section{PEMBAHASAN}

Daun jarak pagar diekstraksi menggunakan 2 metode yaitu ekstraksi cara dingin dengan maserasi dan cara panas dengan refluks, menggunakan pelarut metanol. Rendemen ekstrak hail refluks lebih besar dibandingkan rendemen hasil maserasi. Ekstraksi maserasi merupakan ekstraksi yang dilakukan dengan merendam simplisia dalam pelarut selama 24 jam dan dilanjutkan dengan remaserasi. Pada penelitian ini maserasi dilakukan 1 kali dengan 4 x remaserasi Refluks merupakan metode ekstraksi dengan pemanasan simplisia bersama dengan pelarut selama 3 jam dengan menggunakan pendingin balik. Refluks dilakukan sebanyak 1 kali dan re-refluks 4 kali.

Pemanasan simplisia bersamaan dengan pelarut pada titik didihnya meningkatkan permeabilitas membran sel, sehingga senyawa fitokimia yang terdapat di dalamnya lebih mudah keluar sel dan larut di dalam pelarut. Maserasi dilakukan dengan merendam simplisia 
dnegan pelarut pada suhu ruangan. Apabila dalam proses perendaman telah terjadi kesetimbangan antara pelarut dan senyawa fitokimia, maka proses ekstraksi akan terhenti. Hal tersebut memungkinkan jumlah ekstrak yang diperoleh pada refluks akan lebih besar daripada hasil maserasi.

Rendemen yang dihasilkan pada ekstraksi tersebut sesuai dengan penelitian yang dilakukan oleh Susanty \& Bachmid (2016) dimana ekstrak hasil refluks memiliki rendemen yang lebih besar dibandingkan hasil maserasi. Ekstraksi bertingkat bunga kecombrang dengan pelarut n-heksana dan dilanjutkan dnegan pelarut metanol menunjukkan hasil rendemen yang lebih tinggi pada metode refluks dibandingkan dengan maserasi (Lestari, Rahmiyani, dan Munawaroh, 2014). Besarnya jumlah rendemen tersebut dipengaruhi oleh beberapa faktor, diantaranya jenis pelarut, konsentrasi pelarut, ukuran partikel simplisia, dan lamanya waktu ekstraksi (Suryanto, 2012).

Berbagai senyawa fitokimia terkandung dalam daun jarak pagar, dan sebagian memiliki peranan dalam menghambat pertumbuhan bakteri. Ekstrak metanol daun jarak pagar hasil maserasi mengandung alkaloid, glikosida, saponin, tanin, flavonoid, resin, terpenoid dan steroid (Asogwa et al, 2015). Pengujian aktivitas antibakteri menunjukkan tidak ada aktivitas ekstrak daun jarak pagar terhadap $S$. aureus (Asogwa et al, 2015).

\section{Staphylococcus} epidermidis merupakan flora normal pada kulit manusia, berbentuk bulat dan termasuk bakteri gram positif, tersusun dalam rangkaian tak beraturan dan bersifat anaerob (Syarurachman, et al, 1994).
Penelitian oleh Akinpelu dkk (2009) menunjukkan bahwa zona hambat yang dihasilkan oleh ekstrak metanol : air (3:2) daun jarak pagar pada S. epidermidis sebesar $17 \mathrm{~mm}$ dengan konsentrasi ham bat minimal $5 \mathrm{mg} / \mathrm{ml}$ (5.000 ppm). Sedangkan zona hambat pada $S$. aureus sebesar $15 \mathrm{~mm}$ dengan Konsentrasi hambat $\mathrm{m}$ inimal $0,625 \mathrm{mg} / \mathrm{ml}(625 \mathrm{ppm})$.

Tanin yang terkandung dalam ekstrak daun jarak pagar merupakan salah satu sumber senyawa bioaktif. Flavonoid telah mwnunjukkan kerjanya melalui mekanisme efek terhadap permeabilitas membran dan penghambatan terhadap ikatan membran - enzim seperti ATPase dan fosfolipase2 (Hausteen, 1983). Hal tersebut memungkinkan kerja ekstrak daun jarak pagar dalam menghambat pertumbuhan bakteri. Komponen fenol dalam daun jarak pagar berkontribusi dalam penghambatan mikroba dan nantinya bermanfaat untuk pengobatan herbal.

Perbandingan konsentrasi dan diameter zona hambat menunjukkan semakin tinggi konsentrasi bahan aktif, aktivitas antibakteri semakin meningkat. Hal tersebut sesuai dengan hasil penelitian Puspitasari dkk (2012) yang menunjukkan bahwa semakin tinggi konsentrasi ekstrak buah mengkudu maka semakin kecil daya hambat terhadap pertumbuhan $S$. aureus semakin besar.

Secara keseluruhan daya hambat pertumbuhan bakteri $S$. aureus dan $\mathrm{S}$. epidermidis pada ekstrak hasil refluks lebih tinggi dibanding maserasi. Lestari dkk (2014) menyatakan bahwa kadar total fenol ekstrak hasil refluks lebih tinggi dibanding maserasi. Senyawa polifenol yang terkandung talam tanaman memiliki sifat sebagai antioksidan dan antibakteri. Sufiriyanto dan Indraji (2005) menyatakan 
bahwa bakteri Gram positif tidak tahan terhadap senyawa fenol dan antraquinon.

Senyawa fenol dan antraquinon menekan pertumbuhan bakteri Gram positif karena kemampuan penetrasi senyawa ini dalam dinding sel bakteri. Senyawa fenol dan antraquinon termasuk senyawa yang larut lemak. Golongan fenol mampu merusak membran sel, menginaktifkan enzim dan mendenaturasi protein sehingga dinding sel mengalami kerusakan karena penurunan permeabilitas. Perubahan permeabilitas membran sitoplasma memungkinkan terganggunya transportasi ion-ion organik yang penting ke dalam sel sehingga berakibat terhambatnya pertumbuhan bahkan hingga kematian sel (Damayanti dan Suparjana, 2007).

Kandungan fenol dalam konsentrasi tinggi mampu menembus dan mengganggu dinding sel bakteri dan mempresipitasi protein dalam sel bakteri. Fenol pada konsentrasi yang lebih rendah menginaktifkan sistem enzim penting dalam sel bakteri (Oliver et al., 2001).

Flavonoid merupakan senyawa yang mempunyai efek antibakteri (Djauhariya, 2003). Flavonoid merupakan kelompok dari fitokimia fenolik yang berfungsi sebagai peredam radikal bebas yang sangat kuat dan membantu mencegah penyakit yang berhubungan dengan stress oksidatif serta memiliki aktivitas antimikroba, antikarsinogenik, antiplatelet, antiiskemik, antialergi dan antiinflamasi (Rahmawati, 2009).

Senyawa flavonoid merupakan bagian yang bersifat polar sehingga lebih mudah menembus lapisan peptidoglikan yang bersifat polar daripada lapisan lipid yang nonpolar, sehingga menyebabkan aktivitas penghambatan pada bakteri gram positif lebih besar daripada bakteri gram negatif. Aktivitas penghambatan dari kandungan buah mengkudu pada bakteri Gram positif menyebabkan terganggunya fungsi dinding sel sebagai pemberi bentuk sel dan melindungi sel dari lisis osmotik. Dengan terganggunya dinding sel akan menyebabkan lisis pada sel (Dewi, 2010).

Senyawa terpenoid yang mempunyai daya polaritas sama dengan golongan fenol. Mekanisme kerja dari senyawa terpenoid sama dengan mekanisme kerja dari senyawa fenol yaitu mengganggu proses transportasi ion penting ke dalam sel bakteri. Terpenoid mampu berikatan dengan lemak dan karbohidrat yang akan menyebabkan permeabilitas dinding sel bakteri MRSA terganggu (Nursal,1997).

\section{KESIMPULAN DAN SARAN}

\section{A. Kesimpulan}

1. Diameter zona hambat ekstrak metanol daun jarak pagar terhadap pertumbuhan S. epidermidis paling besar pada konsentrasi 100.000 ppm, sebesar 19,33 mm pada ekstrak hasil maserasi dan 22,67 $\mathrm{mm}$ pada ekstrak hasil refluks

2. Diameter zona hambat ekstrak metanol daun jarak pagar terhadap pertumbuhan S. aureus paling besar pada konsentrasi $100.000 \mathrm{ppm}$, sebesar $31 \mathrm{~mm}$ pada ekstrak hasil maserasi dan 29,67 mm pada ekstrak hasil refluks

3. Ekstrak hasil refluks memberikan hambatan yang lebih besar dibanding ekstrak hasil maserasi terhadap S. epidermidis maupun $S$. aureus

4. Ekstrak metanol daun jarak pagar hasil maserasi dan refluks memiliki aktivitas antibakteri yang kuat terhadap S. epidermidis maupun $S$. aureus namun masih di bawah Klindamycin. 


\section{B. Saran}

1. Perlu pengujian ulang aktivitas antibakteri ekstrak daun jarak pagar terhadap Staphylococcus aureus

2. Bagi peneliti selanjutnya untuk dapat menggunakan hasil penelitian ini berupa pembuatan bentuk sediaan yang baik untuk mengatasi gangguan kulit, terutama jerawat

\section{DAFTAR RUJUKAN}

Akinpelu, D.A., Aiyegoro, O.A., Okoh, A.I., 2009. The bioactive potentials of two medicinal plants commonly used as folklore remedies among some tribes in West Africa. African Journal of Biotechnology 8, 1660 1664.

Asogwa, F.C., Okoye, C.O.B., Okechukwu, P.C., Nzubechukwu, E., Esther A.U., And Chinedu O.E. 2015. Phytochemistry and Antimicrobial Assay of Jatropha curcas Extracts on Some Clinically Isolated Bacteria - A Comparative Analysis. European Journal of Applied Sciences, 7 (1): 12-16.

Dewi, F.K. 2010.Aktivitas Antibakteri Ekstrak Etanol Buah Mengkudu (Morinda Citrifolia, Linnaeus) Terhadap Bakteri Pembusuk Daging Segar [Skripsi]. Fakultas Matematika Dan Ilmu Pengetahuan Alam. Universitas Sebelas Maret.Surakarta

Djauhariya, E. 2003. Mengkudu (Morinda citrifolia L.) Tanaman Obat Potensial, Balai Penelitian Tanaman Rempah dan Obat. J. Perkembangan Teknologi TROL, Vol. XV, No. 1, p. 21

Rahmawati, A. 2009. Kandungan Fenol Total Ekstrak Buah Mengkudu
(Morinda citrifolia). [Skripsi]. Fakultas Kedokteran. Universitas Indonesia. Jakarta.

Lestari T., Rahmiyani I., Munawaroh S. (2014). Pengaruh Metode Dan Variasi Pelarut Ekstraksi Terhadap Kadar Polifenolat Bunga Kecombrang (Etlingera elatior (Jack) r.m.sm). Jurnal Kesehatan Bakti Tunah Husada, 12(1): 88-95.

Nursal, M. dan Nganro, M.R. 1997.Pengaruh Ekstrak Akar Achantus Illicifolius terhadap Pertumbuhan Vibrio parahaemolyticus. Jurnal Biosains, 2 (1)

Sufiriyanto dan M. Indraji. 2005. Uji in vitro dan in vivo ekstrak campuran mengkudu (Morinda citrifolia) dan bawang putih (Allium sativum) pada sapi perah penderita mastitis sub klinis. J. Anim. Prod. 7: 101105.

Suryanto, E., Wehantouw, F. 2009. Aktivitas Penangkal Radikal Bebas dari Ekstrak Fenolik Daun Sukun (Artocarpus altilis F.). Chemistry Progress. 2:1-7

Susanty, Bachmid, (2016). Perbandingan Metode Ekstraksi Maserasi Dan Refluks Terhadap Kadar Fenolik Dari Ekstrak Tongkol Jagung (Zea mays L.). KONVERSI, 5 (2): 8793. 